\title{
PRACTICE IN PLACE IN EMPIRE FORESTRY: OWEN JONES IN CEYLON, AUSTRALIA AND NEW ZEALAND, 1911-55
}

\author{
MICHAEL ROCHE \\ School of People, Environment and Planning \\ Massey University
}

\section{Abstract}

This article traces the career of the forester Owen Jones from his training at Oxford University to his retirement in New Zealand. Taught by the eminent Empire forester Sir William Schlich, Jones joined the Ceylon Forest Department in 1911 and after the First World War was appointed Chair of the Victorian Forestry Commission. In 1925 he left to take charge of New Zealand Perpetual Forests' afforestation program and after the Second World War worked as an independent forestry consultant. Jones exemplified the Oxford Empire forester, but after successes in Ceylon he encountered unexpected opposition in Victoria, which prompted him to depart public sector forestry for a more restricted role in private sector afforestation in New Zealand.

Keywords: forestry, Australia, New Zealand

\section{Introduction}

It is possible to visualise Tom Brooking's publications as situated within a 'triangle' where environmental history, biography and urban social structure are at the corners, as represented by for instance the 'Empires of Grass' project, his biography of Richard Seddon and work undertaken as part of the Caversham project. Contained within the triangle is an array of other work, from a short history of Massey University and a single-volume history of New Zealand, to a history of dentistry in New Zealand, as well as interests in comparative environmental history. ${ }^{1}$

\footnotetext{
1 Tom Brooking, Richard Seddon: King of God's Own (Auckland: Penguin, 2014); Tom Brooking and Eric Pawson, eds, Seeds of Empire: The Environmental Transformation of New Zealand (London: I. B. Tauris, 2011); Tom Brooking, Dick Martin, David Thomson and Hamish B. James, 'The ties that bind: Persistence in a New World industrial suburb, 1902-1922', Social History 24 (1999): 55-73, doi.org/10.1080/03071029908568052; Tom Brooking, The History of New Zealand (Westport, CT: Greenwood, 2004); Tom Brooking, Massey, its early years: A history of the development of Massey Agricultural College to 1943 (Palmerston North: Massey Alumni Association, 1977); Tom Brooking, A history of dentistry in New Zealand (Dunedin: New Zealand Dental Association, 1980).
} 
The image of the triangle is invoked both to make a point about how my own work is situated with respect to Tom's and to provide a rationale for the substance of this article. Whereas Tom's biographies exemplify 'biography as subject', and for me his biography of Jock McKenzie is particularly significant, Seddon's interests in scenery preservation notwithstanding, my biographical work has been more in the vein of 'biography as method' less 'concerned with the internal components of subjectivity [biography as subject] than the external factors that shaped' a life. ${ }^{2}$ Where Tom has written about closer land settlement, my attention has been focused on the timber industry (a still neglected aspect of rural life in New Zealand), early efforts at forest conservation and on discharged soldier settlement as a last pioneering phase of land development. ${ }^{3}$ Whereas Tom and Eric Pawson address the question of what came after the forest was cleared, my own attention has stayed on the forest cover, forest management and afforestation. And for the record, my own interest in the urban has been limited to some enquiries focused on the Workers Dwelling Act. Tom and I have worked largely in parallel planes, but not entirely occasionally we bump up against and sometimes have crossed common boundaries in biography, environmental history and, to a lesser extent, social structure. This article is written then from across the border, indeed across several borders (but not barriers) that surround Tom's academic interests (which also, it ought to be noted, includes a sensitivity to place, particularly, but not limited to, Otago).

The subject of this article is Owen Jones, an imperial forester in Ceylon (now Sri Lanka), Australia and New Zealand. Previously, I have written about Jones and forestry to illustrate ideas of imperial 'careering' and mobilities, an approach developed by David Lambert and Alan Lester. ${ }^{4}$ My earlier work on Jones can also be positioned against an interest in the diffusion of scientific forestry ideas spreading around the British Empire, and indeed into North America. ${ }^{5}$ Elsewhere, the forester John Dargavel writes of 4 'contested forestries' in Australia involving local land department officers, British estate forestry, European and empire systems, and American, with their associated visions. He also notes that the European foresters' vision was 'more diverse than is commonly depicted in the English-language literatures'. ${ }^{6}$ The diffusionist interpretation was challenged by Indian environmental

2 Jake Hodder, 'On absence and abundance: Biography as method in archival research', Area 49 (2017): 455, doi.org/10.1111/area.12329.

3 Tom Brooking, "Busting Up” the Greatest Estate of All: Liberal Maori Land Policy, 1891-1911', New Zealand Journal of History 26 (1992): 78-98; Tom Brooking, 'Use it or lose it: Unravelling the land debate in nineteenthcentury New Zealand', New Zealand Journal of History 30 (1996): 141-62.

4 David Lambert and Alan Lester, 'Imperial Spaces, Imperial Subjects', in Colonial Lives Across the British Empire: Imperial Careering in the Long Nineteenth Century, ed. David Lambert and Alan Lester (Cambridge: Cambridge University Press, 2006).

5 Gregory Barton, 'Empire forestry and the origins of environmentalism', Journal of Historical Geography 27 (2001): 529-52, doi.org/10.1006/jhge.2001.0353; Gregory Barton, Empire Forestry and the Origins of Environmentalism (Cambridge: Cambridge University Press 2002).

6 John Dargavel, 'Contested forestries, contested educations: A centenary reflection', Australian Forester 75 (2012): 16-21, doi.org/10.1080/00049158.2012.10676381. 
historians, who reasserted the significance of place, particularly the importance in India of local conditions in modifying ideas of scientific state forestry. ${ }^{7}$ Some research by environmental historians and historical geographers has attempted a synthesis of training and place to argue that European forestry practices and their modification were important in specific places at particular times. ${ }^{8}$ Brief studies of the foresters Sir David Hutchins and Hugh Corbin support this position. ${ }^{9}$ This article continues in this vein; at its core are the interconnections between Jones' professional training and the impact of place on his forestry practice.

Brett Bennett argues that forestry in India became more 'British' after the establishment of forestry teaching at the Royal Indian Engineering College at Cooper's Hill in England in $1885 .{ }^{10}$ In 1905 the Imperial Forest School shifted from Cooper's Hill to Oxford University, where an Oxford degree, usually in Natural Sciences, became the prerequisite for the Diploma in Forestry. Owen Jones was an Oxford forestry graduate whose profession took him to Ceylon (1911-17), was interrupted by war service, then recommenced in Victoria, Australia (1920-25), and concluded in New Zealand (1925-55). ${ }^{11}$ His 40-year career allows for a prolonged examination of the modifying impact of local conditions, particularly in Australia and New Zealand, on his forestry practices and on the persistence of ideas from his original forestry training at Oxford under Sir William Schlich.

7 K. Sivaramakrishnan, 'A limited forest conservancy in southwest Bengal, 1864-1912', Journal of Asian Studies 56 (1997): 75-112, doi.org/10.2307/2646344.

8 Brett Bennett, 'An Imperial, National and State Debate: The Rise and Near Fall of the Australian Forestry School, 1927-1945', Environment and History 15, no. 2 (2009): 217-44, doi.org/10.3197/096734009X437990; Brett Bennett, 'A Network Approach to the Origins of Forestry Education in India, 1855-1885', in Science and Empire: Knowledge and Networks of Science across the British Empire, 1800-1970, ed. Brett Bennett and Joseph Hodge (Basingstoke: Palgrave Macmillan, 2011), 68-88, doi.org/10.1057/9780230320826_4; Benjamin Weil, 'Conservation, exploitation, and cultural change in the Indian Forest Service, 1875-1927', Environmental History 11 (2006): 319-43, doi.org/10.1093/envhis/11.2.319; Michael Roche, 'Colonial Forestry at its Limits: The Latter Day Career of Sir David Hutchins in New Zealand 1915-1920’, Environment and History 16 (2010): 431-54, doi.org/10.3197/096734010X531489; Michael Roche, 'Forestry as imperial careering: New Zealand as the end and edge of empire in the 1920s-40s', New Zealand Geographer 68 (2012): 201-10, doi.org/10.1111/j.17457939.2012.01234.x.

9 Roche, 'Colonial Forestry at its Limits'; Michael Roche, 'H. Hugh Corbin at the University of Adelaide School of Forestry, 1912-1925’, Australian Forestry Journal 76 (2013): 1-8, doi.org/10.1080/00049158.2013.776927.

10 Bennett, 'A Network Approach', 69.

11 I have retained 'Ceylon' in the text to signal that Jones was part of the British colonial era. 


\section{Owen Jones-The world and work of an empire forester}

Owen Jones (1888-1955) was an archetypal Imperial forester: a public schoolboy and captain of the First XI and First XV who won a scholarship to study at Oxford University. ${ }^{12}$ Jones completed a Natural Sciences degree in 1910, followed by a Diploma in Forestry in 1911 under Sir William Schlich. ${ }^{13}$ German-born and educated, Schlich was the preeminent figure in British imperial forestry; he had completed a forestry $\mathrm{PhD}$ at the University of Giessen in 1866. After joining the Indian Forest Service he rose to become Inspector General of Forests in India (1883-85) and later oversaw the education of imperial foresters as Professor of Forestry at Cooper's Hill (1885-1905) and subsequently Oxford University $(1905-19) \cdot{ }^{14}$

The cornerstone of Schlich's achievement was his 5-volume Schlich's Manual of Forestry, which was published in several editions from 1889 to the mid-1890s. Schlich authored the first 3 volumes, entitled Introduction to Forestry, the Formation and Tending of Woods or Practical Sylviculture and Forest Management. The last 2 volumes were completed by his Cooper's Hill assistant W. R. Fisher. Volume 4, Forest Protection, was adapted from Der Forstschutz by Dr Richard Hess (Professor of Forestry at the University of Giessen) and volume 5, Forest Utilization, was a translation of Die Forstbenutzung by Dr Karl Gayer (Professor of Forestry at the University of Munich) first published in 1863. It was recognised as the standard German work on utilisation. This set of canonical texts made available in English ideas derived from German forestry, tempered by Indian experience. Schlich considered, however, that 'the general principles of sylviculture hold good all over the world'. ${ }^{15} \mathrm{He}$ situated forestry within a political economy whereby the state had particular responsibilities and duties, although there was also a place for privately owned forests. A primary object of forestry was 'the production of forest produce, and the realization of certain other effects' (the latter including climatic and amenity). ${ }^{16}$ This object was to be achieved by silvicultural techniques directed to the long-term maximisation of production of wood per acre, or of the annual monetary return, or of aesthetic or protection forestry ends. This would involve the creation of a 'normal forest' of even age classes for a complete rotation with harvests guided by

12 Sporting achievement was taken as an indicator of the necessary capacity for teamwork and adaptability to the rigours bush camp work.

13 Owen Jones CV [1932]. R3 04/1527/2. Archives New Zealand (ANZ), Wellington.

14 Anon., 'Sir William Schlich', Journal of Forestry, 25 (1927): 5-8.

15 William Schlich, Schlich's Manual of Forestry, vol. 1: Introduction to Forestry (London: Bradbury Agnew, 1896), 159.

16 Schlich, Schlich's Manual of Forestry, 1:59. 
working plans enabled by the collection of growth rate data and calculation of yield tables. The principles contained in Schlich's Manual lay at the heart of the forestry education Jones received at Oxford.

Schlich's writings were situated within a forestry mentality that was governed by 4 assumptions, of 'scarcity', 'stability', 'certainty' and a 'closed economy', which were the product of the particular conditions, including wood shortages faced by German states in the early nineteenth century. ${ }^{17}$ In India, critical historical scholarship sees this 'scientific forestry' manifesto as the redefinition of property rights, demarcation of forests, changes to the composition of forest species, fire control and restrictions on customary use, all injurious to the needs of the local population. ${ }^{18}$ Neither did the 4 assumptions translate well to North America, where a preponderance of old-growth forests resulted in harvests exceeding growth in the process of converting them to 'normal forests', and again in the Depression years of the 1930s when the focus was on an even flow of timber products from the forest to provide socioeconomic stability in towns and communities dependent on forestry. ${ }^{19}$ In Australia and New Zealand, scientific forestry was also comparatively late to appear, lagging because of the efforts put into clearing forests for land settlement, and the political and economic importance of such endeavours.

In 1908, Jones had entered Oxford as a probationer for the forest service of India and Ceylon, opting for the archetypal imperial forestry career path. It was actually a time of change; Jones had been accepted as probationer prior to commencing university study, and as he left for Ceylon in 1911, Oxford lost its monopoly on providing foresters to the Indian Forest Service. ${ }^{20}$ Edinburgh University from 1887 was also training foresters (offering a degree course from 1909), some of whom now found employment in India, while Cambridge also established a short-lived Forestry School in $1907 .{ }^{21}$

After graduating, Jones spent 9 months inspecting long-managed German forests. He prepared a working plan, the epitome of scientific forestry accomplishments, for 20 compartments, totalling 1,580 ha, of forest, in the Mitteldich Ranges near

17 Hugh Raup, 'Some problems in ecological theory and their relation to conservation', Journal of Ecology 52 (supplement) (1964): 19-28, doi.org/10.2307/2426.

18 Ramachandra Guha and Madhav Gadgil, 'State Forestry and Social Conflict in British India', Past \& Present 123 (1989): 141-77, doi.org/10.1093/past/123.1.141; Kalyanakrishnan Sivaramakrishnan, 'The Politics of Fire and Forest Regeneration in Colonial Bengal', Environment and History 2 (1996): 145-94, doi.org/10.3197/ 096734096779522338 .

19 Marion Clawson and Roger Sedjo, 'History of sustained-yield concept and its application to Developing countries', in History of Sustained-Yield Forestry: A symposium, ed. Harold K. Steen (Portland, OR: Forest History Society, 1983), 3-15.

20 J. Ritchie, 'Probationers of the Indian Forest Service', Transactions of the Royal Scottish Arboricultural Society 24 (1911): 212-13, doi.org/10.1080/18324460.1911.10439170.

21 Michael Roche, 'Charles Foweraker: Forestry and Ideas of sustainability at Canterbury University College (1925-1934)', ENNZ: Environment and Nature in New Zealand 11 (2018): 6-23. 
Frankfurt. This document was commented on and signed off by the German forester in charge. ${ }^{22}$ Like his contemporaries, he could to read technical forestry material in German (in Jones' case his French was less polished).

\section{Ceylon, 1911-17}

Appointed as an assistant forester in 1911, Jones was part of the first cohort of professionally qualified officers in the Ceylon Forest Department. Ceylon remained 80 per cent forested, with virtually all the remainder used for agriculture. The forests included a wet, evergreen, tropical rainforest zone around the capital Colombo on the west coast and semi-evergreen monsoon forest on the drier eastern side. ${ }^{23}$ Forests of merchantable quality comprised 3.1 million acres (1.2 million hectares), or 19 per cent of the land area, but less than 10 per cent of the forest by land area was either in, or proposed as, forest reserve. ${ }^{24}$ None of it was under any sort of working plan. A new forest ordinance had been passed in 1907, but the extent of the railway sleeper extraction, along with the amount of firewood gathered and timber felled for public works, was of official concern. In 1909, 1,980 'forest offences' were reported. ${ }^{25}$ These offences, which imperial foresters regarded as 'opposed to all the principles of forest management', included damage done by shifting cultivators and other local peoples denied traditional use rights by the demarcation of forest boundaries and restrictions on access imposed by forestry officials. ${ }^{26}$ Forest offences were dealt with at length by Schlich's Manual, volume 4, under headings of damage, misappropriation and contraventions of forest police. Resource scarcity was also recognised for the first time in 1909, prompting a restriction on sleeper extraction to 50,000 annually. ${ }^{27}$

Signalling a new beginning, in 1909 the Forest Department stated:

Forest exploitation has been directed towards the elimination of over-mature timber which retarded future regeneration of crops, and to the utilization of timber on areas to be alienated for sale, lease or irrigation purposes. ${ }^{28}$

22 Owen Jones, Working Plan for 20 Compartments in the Mitteldich Ranges, 1911. Owen Jones Papers MB 954. Macmillan Brown Library, University of Canterbury, Christchurch.

23 Romas W. Szechowycz, 'Ceylon', in A World Geography of Forest Resources, ed. Stephen Haden-Guest, John K. Wright, and Eileen M. Teclaff (New York: American Geographical Society, 1956), 491-518.

24 Raphael Zon and William N. Sparhawk, Forest Resources of the World (New York: McGraw-Hill, 1923), 357; Arnold Wright, ed., Twentieth Century Impressions of Ceylon: Its History, People, Commerce, Industries, and Resources (London: Lloyds, 1907).

25 Anon., 'Administrative Report of Forest Commissioners in Ceylon for the year 1909', Indian Forester 36 (1910): 694-6.

26 Ibid., 696.

27 Colonial Office, Accounts and Papers: Colonies and British Possessions. Colonial Reports (Annual) Ceylon (London: H.M.S.O.,1909), 35.

28 Ibid., 35. 
Such statements proposing active silviculture intervention, sustained yield management and the efficient extraction of standing timber from land to be dedicated to other uses were foundational forestry propositions of the time. Teak plantations were established at lower altitudes and on the higher, drier areas above 4,000 ft $(1,230 \mathrm{~m})$ plantations of Australian eucalypts and wattles were established on deforested land. ${ }^{29}$ The work of another forester to end up in Australia, the Nancytrained Charles Lane Poole, in Sierra Leone around the same time paralleled Jones' efforts. ${ }^{30}$

Before 12 months had elapsed Jones was sent, on Schlich's recommendation, to Germany for advanced study of forest working plans, forestry statistics and silviculture. This included time at the noted Prussian Forest Statistical Bureau at Eberswalde. ${ }^{31}$ He returned in 1912, and by 1916 was in charge of the Colombo Division with 11 officers and 50 other staff. By 1917, 4,126 acres (1,669 ha) of forest had been planted. ${ }^{32}$ That year he enlisted, and served for the remainder of the war, in the Royal Flying Corps.

In Ceylon, equipped with the techniques and outlooks of imperial forestry, Jones had faced and responded to the 3 problems of reducing unsustainable levels of demand for railway sleepers and timber public works, of ongoing forest offences and of the difficulties of gazetting areas as forest reserves (requiring the investigation and extinguishing of complex land titles and use rights previously granted by the Dutch, Portuguese and Sinhalese). ${ }^{33}$ Progress had been limited by the time of his departure. Ceylon posed challenges, but Schlich's training appeared to provide expert technical solutions.

The full extent of difficulties faced by Jones and his colleagues was identified at the 1923 British Empire Forestry Conference. From 1905, when all forests came under the sole administrative charge of the Forest Department, its role had been judged largely on its capacity to supply railway sleepers, timber and firewood to government departments, establishing local yards for timber and firewood sales, and its ability to operate on the basis of revenue obtained from the sale of timber licences. To 1914, little real effort had been made to balance harvests against annual growth increments. Indeed, many of the forest reserves contained little merchantable timber. Afforestation efforts were applauded. But major challenges remained. These ranged from combatting the issuing of 'bogus private removal permits to make away

\footnotetext{
29 Zon and Sparhawk, Forest Resources of the World.

30 John Dargavel, The Zealous Conservator: A Life of Charles Lane Poole (Crawley, WA: University of Western Australia Press, 2008).

31 Michael Roche, 'Owen Jones: Inaugural Chair of the Forests Commission of Victoria, 1919-1925, Australian Forest History Society Newsletter 74 (2018): 4-5.

32 Colonial Office, Accounts and Papers Colonies and British Possessions Colonial Reports (Annual) Ceylon (London: H.M.S.O., 1917), 10.

33 W. McNeill, 'State Forests in the Empire', Empire Forestry Journal 17 (1938): 195-200.
} 
with timber' to crippling amounts of administrative work, to 'the frequent failure of natural regeneration to persist when found'.$^{34}$ Perhaps this situation was also a part of Jones' later decision to apply for a senior position in Victoria. But it also points to something more than individual decisions and choices: the universality of forestry principles that Schlich was so confident about were perhaps not so apparent on the ground, particularly in environments far removed from continental Europe where these ideas were developed from the seventeenth to the nineteenth centuries.

\section{Victoria, $1920-25$}

With an eye to career advancement, Jones chose not to return to Ceylon after the war. Instead, in 1919, newly married, he secured at the young age of 31 a senior position in Australia as the foundation chairman of the 3-person Victorian Forest Commission (VFC). Victoria was only around 14 per cent forest-covered, approximately 8 million acres (3.2 million hectares), with only 5.3 per cent of it merchantable forest, and with 45 per cent of timber consumption, around 10 million cubic feet per annum $\left(283,168 \mathrm{~m}^{3}\right)$, being met by imported softwoods. ${ }^{35}$ The VFC was intended to be 'a corporate and politically semi-independent' body maintained by a fixed annual grant of $£ 40,000$ from the Treasury. ${ }^{36}$ Jones initially enthused that the legislation and the commission 'at one strike' would remove the forest 'to a large extent from political influence' and represented a 'genuine attempt to place forestry control upon a more definite and scientific footing. ${ }^{37}$ Difficulties were encountered elsewhere in Australia: Lane Poole resigned as Conservator of Forests in Western Australia in 1921 over what he regarded as political interference. ${ }^{38}$

Although applauding the intent to create working plans for all forests in Victoria, Jones was concerned that little provision was made for securing professionally trained forestry staff. He favoured creating an Australia-wide forestry school at the University of Sydney, which was consistent with the German model of linking forestry training with the university, whereas Lane Poole favoured a French-derived 'school in the forest' alternative to serve Australian needs. ${ }^{39}$

Six months after arriving, Jones described his first impressions of Victorian forestry. He balanced his lament about the loss of the state's forest to axe and fire with the comment that he had no quarrel with the legitimate demands of land settlement.

34 J. D. Sargent, Report of the Forest Authority for Ceylon prepared for the British Empire Forestry Conference,

Ottawa, Canada 1923 (Colombo: Government Printer, 1923), 7, 20.

35 Zon and Sparhawk, Forest Resources of the World.

36 Owen Jones, 'Forestry in Victoria', Empire Forestry Journal, 5 (1926): 98.

37 Ibid., 98.

38 Dargavel, The Zealous Conservator.

39 Roche, 'H. Hugh Corbin', 1-8. 
His overall thrust was forward-looking; he also carefully couched his call for an effective forest policy in such a way as to win the support of the rural development lobby, frequently the fiercest opponent of forestry in settler states:

Forests must be developed by roads, tramways or railways, they must be cultivated and improved so that their volume production reaches a higher standard, and above all, they must be so regulated as to produce constant and equal yield, so that local industries may be brought into being by the assurance of unfailing supplies. It is in this that lays the chief function of the forester. ${ }^{40}$

This statement echoes that of the Ceylon Forest Department of 1909 and, more importantly, aligns with the 'stability' state forestry assumption noted earlier. Jones resorted to Continental European examples to make his point. Victoriass settler population, like that of Britain, he suggested, looked on foresters as 'little more than game keepers and policeman-rangers whereas the duty of the foresters in France, Germany and Switzerland was neither this nor tree planting' but responsibility for 'natural regeneration - that is to say on the growing up of seedlings'. ${ }^{41}$ This, he stressed, was cheaper than planting, but was a hugely skilled task and 'the highest test of the forester', a point he returned to much later in New Zealand. ${ }^{42}$ Afforestation he identified as a 'government concern because, owing to the slow growth of trees, individuals cannot be expected to do the work necessary. ${ }^{43}$ His initial assessment was that Victoria needed fire protection, improved road and rail infrastructure for timber extraction and a public education program so the proper nature of forestry could be explained.

Jones was energetic in endeavouring to educate the public. In helping launch a statewide Tree Lovers' League in 1922, he began by referring to John Evelyn's famous treatise Sylva before paraphrasing Lord Novar's condemnation of British people's attitudes to forestry at the 1920 Empire Forestry Conference:

Owing to a general apathy in regard to our forefathers in Great Britain, an apathy which is not local or periodical, but is permanent and racial, and which has been intensified by the conditions prevalent in a new country, where forest land has of necessity to be cleared to permit of settlement and where in consequence the forest is frequently looked upon as an enemy to be fought in every possible way, there is much ignorance and misconception of the meaning and aims of forest conservation. ${ }^{44}$

\footnotetext{
40 Owen Jones, 'Victoria's forests, some first impressions', The Gum Tree 5, no. 14 (1920): 7.

41 Ibid.

42 Ibid., 7-10; Owen Jones, 'Some Re-establishment Problem', New Zealand Journal of Forestry 5, no. 1 (1944): 9-19.

43 Jones, 'Victoria's forests', 7.

44 Owen Jones, 'Mr Owen Jones at the University Science Club', Australian Forestry Journal 4, no. 9 (1921): 270.
} 
He positioned forestry as a business, drawing attention to the net revenue of over $£ 1$ million it had contributed to government revenues in India in each of the 5 years since 1918. Managed Continental European forests, he observed, yielded from 10s to $£ 110$ s per acre per annum.

To the Melbourne University Science Club Jones delivered a lantern-slide lecture in which he laid down 'the two principle [sic] functions' of forestry as being 'the provision of useful material and the conservation of water supply'. ${ }^{45}$ Bush fires he recognised as a special danger, which in India and Germany had been alleviated by clearing up in the forest and through the use of firebreaks. He highlighted the revenue timber returned to the state in Prussia and Saxony, and furthermore observed 'that in Europe the forests gave a useful employment to one man per 100 acres'. ${ }^{46}$ He noted 'one of the foresters" principal objects was to provide for the future by ensuring the reproduction of forests. ${ }^{47}$ By implication this was to be through the regeneration of indigenous forest, though he did agree that in some localities exotic trees and eucalypts ought to be planted.

Speaking to the heads of the state forestry departments, few then being professionally qualified, and their respective ministers, at the 1922 Interstate Forestry Conference in Brisbane, he turned to the myth of inexhaustible forest resources. His vision of the future for Victoria now readjusted to local place-based realities, included sizable exotic plantations, along with managed natural regeneration. He repeated his argument about 'racial' apathy towards forestry, while emphasising that forestry and agriculture actually had shared interests: 'timber is a crop capable of reproduction not a mine bound to be exhausted'. ${ }^{48}$ Continuity he described as the 'keystone of forestry'. ${ }^{49}$ Arguably, he was conflating the classic assumption of 'stability' and 'certainty', but Victoria imported large amounts of timber and was anything but a closed economy.

Jones reached out to a wider audience at the Australasian Association for the Advancement of Science Congress in Melbourne in 1921. Addressing the relationship of forestry to engineering and architecture, he outlined forestry's main function as 'the tending and management of woodlots so as to produce a maximum and sustained yield on a sound continued basis'. ${ }^{50}$ This restates the 'stability' assumption of a constant and regular flow of wood for the economy. Australia urgently required trained foresters to develop forest working plans, a need that in his view ought to have been met through the creation of a federal forestry school, a sensible but

45 Ibid., 269

46 Ibid.

47 Ibid.

48 Owen Jones, 'Forestry and National Welfare', Australian Forestry Journal 5 (1922): 89.

49 Ibid.

50 Owen Jones, 'Forestry in relation to engineering and architecture', Australian Forestry Journal 4 (1921): 134. 
fraught proposal. ${ }^{51}$ While Jones could quote an unnamed visiting French forester to the effect that Australian foresters were like 'generals without officers', itself a reflection of the authoritarian element of French forestry, he also paraphrased former US President William Howard Taft that 'real conservation involves wise use, non wasteful use in the present generation, combined with every possible means of preservation for succeeding generations'. ${ }^{52}$

The VFC Report for 1920 highlighted dual problems of political pressure for the alienation of forest lands for settlement, and public scepticism about the purpose of forestry. Adding to the challenge was the target set at the State Premiers' Conference in 1920 of 24.5 million acres (9.9 million hectares) of forest reserves for all of Australia; Victoria's quota was to be 5.5 million acres ( 2.2 million hectares), but at the time only 4.1 million acres (1.6 million hectares) were reserved. ${ }^{53}$ The VFC stressed, and this was surely Jones' phrasing, 'Victoria has a useful asset in its forests, and it is only just to expect that they should be managed so as to produce a fair return'. ${ }^{54}$ Forestry in the state faced 2 major silvicultural problems: 'the large areas of mature or over-mature timber' and a lack of natural regeneration in some of the drier forest areas, attributed to rabbits. ${ }^{55}$ By 'over-mature' they meant that these forests comprised very old trees, so that net annual growth was low and hence the annual sustainable harvest would also be low if it had to equate with growth. By thinning and felling they would create a 'normal' forest of even age classes and be able to increase the sustainable harvest. ${ }^{56}$ In other areas exotic plantations were growing well, but for their 'economic working' sufficient land needed to be available to plant 'approximately equal amounts' for the 20 - to 30 -year rotation. ${ }^{57}$ Instances of over-cutting leading to localised resource exhaustion in 15 to 20 years were noted..$^{58}$

Increased revenue from VFC forestry operations was reported in 1921-22 and active 'thinning and improvement' of stands was carried out to promote regeneration and tree growth as well as in order to reduce the fire risk. ${ }^{59}$ The first major effort to survey and inspect potential areas for forest reserves involving some 170,000 acres $(68,795 \mathrm{ha})$ of hardwood forest was carried out in East Gippsland. Field inspections showed these areas to be of great forestry potential because of the amount of

\footnotetext{
51 Michael Roche and John Dargavel, “'Imperial Ethos, Dominions Reality”: Forestry Education in New Zealand and Australia, 1910-1965', Environment and History 14 (2008): 523-43, doi.org/10.3197/096734008X368420; Roche, 'H. Hugh Corbin', 1-8.

52 Owen Jones, 'Forestry in relation to engineering and architecture', 199. Ironically, then, it was Taft who dismissed Pinchot as head of the US Forest Service in 1910.

53 Victorian Forestry Commission, 1920, 8.

54 Ibid., 18 (my emphasis).

55 Ibid., 13

56 David Demeritt, 'Scientific forest conservation and the statistical picturing of nature's limits in the Progressiveera United States', Environment and Planning D 19 (2001): 431-59.

57 Victorian Forestry Commission, 1920, 12.

58 Victorian Forestry Commission, 1920-21, 6.

59 Victorian Forestry Commission, 1921-22.
} 
regeneration, 'to a very unusual extent not over mature, there being extensive areas of nearly mature forest, semi mature, and also of vigorous young pole and spar timbers. ${ }^{60}$ The VFC immediately sought to have this area protected under the Forests Act 1918, but the lack of government action was recorded with concern. The absence of action over reserving forest in East Gippsland was returned to in 1922-23. ${ }^{61}$ The difficulty of securing adequately trained officers was also noted. Silvicultural treatment of 'mature and over-mature trees' continued and the example of Tunstall Reserve was cited, where thinning and clearing of debris at the cost of $£ 528$ had been offset by fuel wood sales from removals of $£ 1,048 .{ }^{62}$ Deficiencies in the legislation were now apparent, notably a too-limited capacity to secure local assistance in forest fire-fighting, along with inadequate fines and a complicated process for securing prosecutions. Yet generic solutions to these problems were laid out in Schlich's Manual, though, as Jones was finding out, they were difficult to apply in Victoria.

In 1923 Jones represented Australia at the second Empire Forestry Conference, held in Ottawa. After forcefully presenting the report on Australia, he returned to the familiar theme of what he saw as weaknesses in the British population's attitude to forests. Drawing on his time in Ceylon, he contributed to a discussion on, as he saw it, the damage done by shifting cultivation to forests and the development of an empire-wide policy of exclusion. Here Jones actually adopted a more permissive attitude than some notable empire foresters, arguing that controlled shifting cultivation was possible and that, in conjunction with afforestation, forest cover could be restored, against the traditional colonial forestry insistence that shifting cultivators must be excluded from the forest. ${ }^{63} \mathrm{He}$ also seconded one of the formal motions of the conference on soft woods and was a member of several of the conference committees, including that on education, on the publication of technical and official information, on fire protection and on shifting cultivation.

The first major crisis Jones faced dated to early 1921 when the Victorian Minister of Lands sought to release areas for land settlement that the VFC deemed essential for forestry. The minister adopted an anti-forestry stance in directing that in the future Lands Department officials alone would judge if forest-covered land was to be selected for settlement. ${ }^{64}$ In 1924 Jones faced another major challenge when the Victorian Lands Department announced plans to expand settlement into the

60 Ibid., 4.

61 Victorian Forestry Commission, 1922-23.

62 Ibid., 5.

63 S. Ravi Rajan, 'Foresters in the politics of colonial agroecology: The case of shifting cultivation and soil erosion, 1920-1950', Studies in History, n.s. 14 (1998): 217-36, doi.org/10.1177/025764309801400204. While in Ceylon, Jones had undertaken a special investigation of 'hill country fuel areas'—see Michael Roche, 'Owen Jones: Inaugural Chair of the Forests Commission of Victoria, 1919-1925', Australian Forest History Society Newsletter 74 (2018): 4.

64 The Argus (Melbourne), 20 October 1921, 7. 
heavily forested Otway Ranges. The VFC lamented that the area of forest reserve in the state had not been meaningfully increased and, furthermore, still remained at 1.5 million acres $(607,017 \mathrm{ha})$, well below the 5.5 million-acre (2.2 million-hectare) state target. With resignation they noted that the only solution is to arrange for our own supplies by setting aside adequate areas and by making available the necessary funds for their development'. ${ }^{65}$ Impetus came from data presented at the Empire Forestry Conference in Ottawa, which pointed to a looming global softwood shortage. Australia was considered to be one of the first countries likely to suffer 'from a timber shortage'. ${ }^{66}$ The VFC report thus noted, 'It is imperative therefore, for us to provide against such a contingency both by conserving and developing our indigenous forests and by establishing plantations of softwoods on suitable areas' ${ }^{67}$ Perhaps a measure of the new vigilance compared to previous years was that there were 80 convictions for breaches of forest law in $1924 .{ }^{68}$

In 1923 the VFC suggested that the climate of the state was excellent for Monterey pine (Pinus radiata) since it would grow on poorer-class non-settlement land and mature in an exceptionally fast 30 years. This new knowledge would later provide the stepping stone to a further phase of Jones' career.

The VFC report for 1924-25 claimed that it had been a notable year in the 'forest history of Victoria'; not only had forest revenues increased, but 179,600 acres (72,680 ha) of river red gum (Eucalyptus camaldulensis) and black box (Eucalyptus largiflorens) forest had been reserved along the Murray River. Even so, borrowing Lane Poole's phrase, Jones suggested that 'the desired "forest conscience" has yet to be generally awakened'. ${ }^{69}$ Jones now turned to ongoing pressures on forest alienation, noting 'this adverse influence culminated during the year in a determined effort to alienate from the Otway an area which would virtually have meant the extinction of the famous forest' ${ }^{70}$ In 1923 the Lands Department first proposed to alienate 21,000 acres $(8,298 \mathrm{ha})$ of forest land in the Otways. ${ }^{71}$ In the press, Jones said it would 'be a calamity' if the area was excised from the larger Otway Forest Reserve and dismissed as 'farcical' the view that the area was unsuitable for forestry because the timber was over-mature and riddled with white ants: its real importance was that 'the forest contains the most promising growth of blue gum saplings that is to be seen in the State'..$^{72}$ By 1925 Jones, though not without difficulty, had persuaded the state cabinet to abandon what by this time was a plan for only 12,000 acres $(4,856 \mathrm{ha})$ to be transferred from the VFC to the Lands Department. ${ }^{73}$ In his report to the

\footnotetext{
Victorian Forestry Commission, 1923-24, 1.

6 Ibid., 1.

67 Ibid., 2.

68 Ibid., 4.

69 Victorian Forestry Commission, 1924-25, 1.

70 Ibid.

71 The Argus, 4 May 1923, 5.

72 Ibid., 8 April 1925, 26.

73 Ibid., 6 May 1925, 17.
} 
cabinet, Jones described the 12,000 acres as not only somewhat rugged country, by implication hardly suitable for settlement, but also comprised of 'some of the most beautiful hardwoods of southern Australia ... much of which would give a yield of over 50,000 super feet to the acre' $\left(291.5 \mathrm{~m}^{3} / \mathrm{ha}\right) \cdot{ }^{74}$ Noting that forestry arguments eventually prevailed, but showing signs of wearying of the struggle, he lamented that the argument could be relitigated and that the land clearance lobby had 'but once to win the day and the forest is destroyed for all time'. ${ }^{75}$ These were prophetic words, for in 1929 the Lands Department, after a cabinet subcommittee decision in their favour, gained 7,000 acres (2,833 ha) of blue gum forest in the Otway Ranges for settlement purposes. ${ }^{76}$

The immediate aftermath of 'victory' for the Otway forests in 1925 was personally distressing. Jones was harshly criticised by some state politicians, who also urged that his salary not be increased from $£ 1,000$ to $£ 1,250$ as proposed in the Forests Bill of $1924 . .^{77}$ Jones, unhappy since 1922, now resigned, citing the hostility of the Lands Department to forestry. In his letter of resignation he noted, 'the reception accorded to the Amending Forest Bill and to the proposal to increase the salaries of the Commissioners has, however, made it evident both that appreciation of forestry as a national question is confined largely to the abstract ideas, and also that I have personally little to expect in the way of advancement'. ${ }^{78}$ The ministers closed ranks and defended the progress of the Forests Bill through parliament. The Minister of Lands 'categorically denied' Jones' complaints, instead pointing to the 'uncompromising' attitude of the VFC with regard to exchanging crown land for forest lands. William Everard MLA, a special adversary, accused Jones of 'quarrell[ing] with the Lands department, and when he could not get his own way he whined like a spoilt child'. ${ }^{79}$

Jones enjoyed successes with the VFC, but he became disillusioned over the need to constantly battle to establish forestry in the state sector. Announcing his departure, the commission lauded his knowledge of conifers and the efforts he had made to advance afforestation work in the state, though the total area was only 2,239 acres (906 ha) across 24 plantations, but omitted mention of forest reserves and indigenous forest. ${ }^{80}$ After leaving Victoria, Jones unburdened himself in writing about 'bitter, protracted, and often unsuccessful struggles against ignorance, prejudice, greed and self-seeking..$^{81}$ He bemoaned the lack of a 'forest conscience' and he despaired of the 'Australian prejudice against "imported" men and the sentiment in favour of

74 Ibid.

75 Victorian Forestry Commission, 1924-25, 2.

76 The Argus, 29 June 1929, 25.

77 Ibid., 30 October 1925, 13; ibid., 5 November 1925, 11.

78 Jones to Minister of Forests, 21 September 1925. Resignation of Mr Owen Jones Chairman of the Forestry Commission. VPRO 11563 P0001 47/1403. Public Record Office, Melbourne.

79 The Argus, 6 November, 1925, 11.

80 Victorian Forestry Commission, 1925-26, 15.

81 Owen Jones, 'Forestry in Victoria', Empire Forestry Journal 5 (1926): 87. 
appointing local men to local positions' ${ }^{82}$ General principles of forestry science that he adhered to were also challenged in Victoria, ecologically where some forests were not regenerating naturally, and politically by the advocates and agents of land settlement. That said, Jones' faith in the canons of his forestry education remained. His efforts in Victoria had largely revolved around forest demarcation, with only preliminary silvicultural and afforestation work. Many of the approaches laid out in Schlich's Manual were impossible to impose in the polity of Victoria as a settler state. The deepest challenge was that politicians in Victoria were sceptical of the very idea of the forester as an independent supra-political natural resource manager and Jones by temperament seemed easily wounded by personal attacks from local MPs seeking to promote closer land settlement and the release of forests in their electorates.

\section{New Zealand, 1925-55}

In 1925 Jones inquired about a chair in Forestry advertised at Auckland University College, but did not make a formal application. Later that same year he travelled privately to New Zealand to inspect a large afforestation company, New Zealand Perpetual Forests. At a moment of defeat in Victoria, new forestry opportunities had emerged based on a new plantation forest species displaying rapid growth rates. On his return to Melbourne, Jones accepted a position as New Zealand Perpetual Forests Forestry Superintendent. Newspaper reports suggested he was doubling his $£ 1,000$ salary but that the real impetus for his departure lay in the unsympathetic political response to forestry and the 'mutilation' of the Forestry Bill then before the state parliament. ${ }^{83}$ Before leaving Australia he gave a lecture to the Victorian Institution of Surveyors, at which he returned to an old theme but with an edge of bitterness: 'It is unfortunate that the British of all great nations had displayed the greatest apathy towards forestry, and in Australia that apathy was racial and permanent. ${ }^{34}$

New Zealand was 26 per cent forested (17 million acres or 6.9 million hectares) when Jones arrived. ${ }^{85}$ William Sparhawk and Raphael Zon noted 35,344 acres (14,302 ha) of state exotic plantations were established to 1919, with more planned. Schlich, however, had expressed concern about the virtual abandonment of indigenous forest management in favour of dependence on exotic plantations for long-term timber supplies, as proposed by the Royal Commission on Forestry in $1913 .{ }^{86}$ Rapid growth rates for exotic trees attracted the interest of private syndicates in the $1920 \mathrm{~s}$. New Zealand Perpetual Forests, established in 1923, was the largest of the 30 or so

82 Ibid., 100

83 The Argus, 23 October 1925, 11; ibid., 24 October 1925, 38.

84 Ibid., 7 November 1925, 30.

85 Zon and Sparhawk, Forest Resources of the World.

86 William Schlich, 'Forestry in the Dominion of New Zealand', Quarterly Journal of Forestry 1 (1918): 1-28. 
afforestation companies and had purchased large areas of open land in the central North Island. Then unsuited to pastoral farming because of an unrecognised cobalt deficiency that produced 'bush sickness' in sheep, it was suitable for tree planting. Pinus radiata could be grown to merchantable size in 25 years, even faster than in Victoria. As Forest Superintendent, Jones headed the afforestation program: in 1926 the company planted 30 million trees on 46,000 acres (18,615 ha) of land, which he claimed was a record for the British Empire. ${ }^{87}$ As well as the economic benefits, he also believed the afforestation effort was converting wastelands into scenically attractive countryside. In the Empire Forestry Journal he described this afforestation effort as transformative: 'there is now every prospect that this vast area, hitherto abandoned almost entirely to the wild horse and the wild pig will blossom under the hand of the forester into an important tree-producing region' ${ }^{88}$

Jones noted that the company favoured Pinus radiata 'by reason of its remarkably rapid growth, its hardiness, its adaptability, and the general all round utility of its timber' ${ }^{89}$ His professional training recognised, however, monoculture vulnerability and that 'it is not desirable to have excessively large areas of one species only'. ${ }^{90}$ Matching species and locality, the company planted some areas in the more frostresistant Ponderosa pine, along with small areas in Douglas fir (Pseudotsuga menziesii), Coast redwood (Sequoia sempervirens), Weymouth pine (Pinus strobus), Maritime pine (Pinis pinaster), Corsican pine (Pinus nigra subspecies laricio), Monterey cypress (or Macrocarpa, Cupressus macrocarpa) and some poplar species. But in 1927 Pinus radiata by far dominated the company's planting, at 29.7 million or 70 per cent of their trees (eventually exceeding 80 per cent), with 18 per cent Pinus ponderosa, 7 per cent Douglas fir, and the reminder in Coast redwood, Macrocarpa, Weymouth pine and Maritime pine. ${ }^{91}$ In 1927 New Zealand Perpetual Forests also shifted from $8 \times 8$ feet to $9 \times 9$ feet planting in view of the Pinus radiata growth rates (10 to 12 feet in 3 years). In 1928, Jones approved the use of more time-efficient pitting and large-scale planting techniques, and adjusted the standard planting distances. Building on locally accumulated knowledge, these forests were created in far less time and in a less labour-intensive manner than Schlich's Manual outlined.

Jones also successfully managed the large labour force by encouraging extramural activities such as camp rugby competitions for the men. Patronisingly, Jones also commented:

87 Owen Jones, 'An Afforestation Company's Operations in New Zealand', Empire Forestry Journal 7, no. 1 (1928): 64-75.

88 Jones, 'An Afforestation Company's Operations', 66.

89 Ibid., 70

90 Ibid., 71.

91 H. H. Corbin, Progress Report No 5 on the Forestry Operation of New Zealand Perpetual Forests Limited, 1927. F1 423 29/5/4 pt 2. ANZ, Wellington. 
A considerable proportion of the labour force, particularly amongst the actual tree-planters, are Maoris. The Maoris take a real interest in tree-planting and provided they are properly handled and due attention is paid to their little peculiarities, which they have no less than the rest of mankind, they render satisfactory service. Being naturally of a musical disposition they experience little difficulty in amusing themselves during the evenings, no small factor in promoting contentment in camp life; they accept without undue grumblings the discomforts inevitable during cold, wet weather; their mercurial temperament is seldom downcast for long, and they can and do smile cheerfully under most circumstances. ${ }^{92}$

As new planting was wound down in the mid-1930s his role in the company diminished. In 1938 he announced the introduction of a pruning program as part of the closer silvicultural management of the company forests and a return to core forestry principles, but this coincided with the directors' turning their attention to utilisation, with plans for their own sawmill and schemes for a pulp mill. ${ }^{93}$

Jones had toyed with leaving New Zealand Perpetual Forests as early as 1932 when he was the preferred candidate for the position of Railways Department Forestry Officer, but the low salary and their refusal to let him engage in private consulting work in his own time led him to decline their offer. ${ }^{94}$ In 1940, he volunteered for the 14th New Zealand Forestry Company, in which for a time he served as captain and commanding officer in Britain. Following his return, New Zealand Forest Products, now fully engaged in planning for pulp and paper manufacture and with little interest in silviculture, retained his services only as a consultant. He continued working as a forestry consultant, one of only a few in the country, until his death in 1955 .

Jones remained dedicated to his profession. A respected figure, almost alone amongst the company foresters, he enjoyed a good working relationship with the State Forest Service in terms of purchasing seed and securing logs of various Pinus species from state plantations for testing, along with obtaining other scientific data. ${ }^{95}$ One of the foundation members of the New Zealand Institute of Foresters in 1928, Jones later established a Rotorua Branch and in 1946-48 served as national president of the institute. His 1948 presidential address concluded by considering the long-standing question of whether the institute ought to be a professional society or one 'devoted primarily to narrow vocational interest'. ${ }^{9}$ For Jones it was unreservedly the former, and he believed that the large plantation forest estate meant that the future was bright, though he saw a place for those engaged in production and utilisation of both

92 Jones, 'An Afforestation Company's Operations', 69.

93 New Zealand Forest Products 1940 Report AGM. BBAE 15470986 1916/1950. ANZ, Auckland.

94 Jones to Acting Managing Director New Zealand Railways, 9 December 1932. R3 04/1527/2. ANZ,

Wellington.

95 BAFK 1466 246c 29/5/32, F 1487 29/5/103, F1 29/5/4 part 3 and part 4. ANZ, Auckland.

96 Owen Jones, 'Our Institute', New Zealand Journal of Forestry 5 (1948): 366. 
indigenous and exotic forests and avowed that the institute should never become 'a mere departmental adjunct'. ${ }^{97}$ Jones' own career after arriving in New Zealand had turned exclusively towards exotic forestry and the private sector, away from the stresses and dissension of the public sector that he had experienced in Victoria. By moving into the private sector, he no longer had to make politically unpopular decisions about resisting the spread of settlement. Instead, he now operated on a more restricted set of professional practices regarding afforestation activity. The work was technically challenging because of the scale of planting and the trials of working with a relatively unfamiliar species. But even here he was thwarted over the introduction of more advance silvicultural techniques.

A sign of his dedication and commitment to forestry was to be found in his signing off on Auckland forestry student Lindsay Poole's report on some New Zealand Perpetual plantations in 1929, replicating Jones' own experience in Germany in $1911 .{ }^{98}$ An imperial forester to the end, Jones was remembered with an obituary in the Empire Forestry Journal. In his will he endowed money for a scholarship at his old school to fund a student to study forestry at Oxford. ${ }^{99}$ Jones' forestry practice had evolved in response to the possibilities and limitations imposed by his employment in New Zealand Perpetual Forests and the successor company New Zealand Forest Products. Later, having weighed up the case for natural regeneration after clear felling with some degree of afforestation, he reached the view that 'despite difficulties natural regeneration should be the ultimate aim'. ${ }^{100}$ This was a restatement of principles to be found in Schlich's Manual of Forestry.

\section{Conclusion}

Owen Jones, by education and early career, was a model imperial forester. He has a place in imperial forest history in Ceylon, where he was largely engaged in forest demarcation work and where, as in India, 'forest offences' tracked the resistance of local people to state efforts to exclude them from the forests. His ideas, based on Schlich's teaching, stressed the universality of silvicultural principles. In Ceylon, Jones was part of a cadre of imperial administrators. Forestry problems were to be solved by the top-down imposition of new regulations and practices taught at Oxford and contained in Schlich's Manual of Forestry. Ceylon offered a site where the full range of forestry principles could be applied (including plantations of Australian eucalypt species). Yet even here it was not simply a case of the application

97 Ibid., 367

98 A. L. Poole, Diary of work during vacations-Xmas 1928 and May 1929-N.Z. Perpetual Forests Ltd, Putaruru and North Auckland Land Development Corporation Ltd, Keri Keri. Scion Library, Rotorua.

99 Jones, Owen. Rotorua Forester. BCDG 4421 25/ 85/1955. ANZ, Auckland.

100 Owen Jones, 'Some Re-establishment Problems', New Zealand Journal of Forestry 5, no. 1 (1944): 18. 
of general principles: the number of prosecutions for 'forest offences' points to ongoing local resistance to forest demarcation, and some of the natural forests were not regenerating.

In Victoria and New Zealand the situation was more complicated. Victoria was a settler state with an Arcadian vision based on pastoral farming, but where suitable land, invariably forest-covered, was in short supply by the time Jones joined the VFC. State agencies such as the Lands Department clashed with the VFC, the former seeking to release land to settlement and the latter to demarcate areas as state forests. Settler politicians were vocal in their opposition to the efforts of the VFC, seeing it as blocking the legitimate needs of land settlement. The environmental and ecological conditions were also such that a lack of natural regeneration in some forests posed an additional management challenge. As chair of the VFC, Jones was neither as zealous as Lane Poole, nor as ebullient as Leon Ellis, Director of Forests (1920-1928) in New Zealand, and did not withstand harsh political criticism and pressure as well as either of his contemporaries. He emerges as perplexed, even a little naive, in his public statements when the logical case for forestry was not followed through on by the state government. If he had been less reasonable and more strident, stubborn and bloody-minded even, and played the political game more effectively, then perhaps he might have accomplished more in the public sector in Victoria. But this was not the imperial forestry tradition in which Jones was trained; he after all was the expert offering sound, dispassionate and detached advice above the hurly-burly of politics. His writings about forestry, although not voluminous, nevertheless display considerable depth and awareness of his professional canons.

In New Zealand there were strong parallels with the settler state in Victoria in the desire for continued closer land settlement on forested crown lands. More of the country, however, was under forest than in Victoria, and some senior political figures, notably Sir Francis Bell, supported state forestry. Political opposition to forestry was never as strident in New Zealand as in Victoria. The competition between the Lands Department and State Forest Service was never as strife-ridden. Besides which there was land unsuitable for settlement, in the form of the cobaltdeficient pumice lands of the central North Island, which was eminently suitable for afforestation by state and private companies. The rapidity of tree growth captured the attention not only of the state but also the commercial sector, which raised considerable sums in private investment. Jones came to a situation in New Zealand where there were considerable technical challenges pertaining to the scale of planting and environmental conditions, not to mention that Pinus radiata was not a proven plantation species. Accordingly, as a company forester he now drew on only part of his broader forestry training and over time enlarged his expertise with local experimentation in planting Pinus radiata. While not on display, his commitment to natural forest regeneration as a core principle remained. 
Ceylon, Victoria and New Zealand, the places Jones' career played out over 4 decades, each brought different combinations - different facets of his professional training to the fore: broadly based British-Indian infused practices in the former; a somewhat reduced set of practices, mainly relating to state forest demarcation but with some limited silvicultural and afforestation work, in Victoria; and a much narrower suite of afforestation-related activities in New Zealand-reflective of his position in New Zealand Perpetual Forests. This narrowing of his forestry practices and shift to private-sector employment did, however, mean that there was no repetition of the personal vilification that Jones had suffered in the VFC. But were such excisions absolute and enduring? Jones' views as President of the New Zealand Institute of Foresters in the late 1940s suggest not-he remained true to core ideas about the natural regeneration of forests even though he was never able to implement them in the New Zealand environment.

Returning to the bigger question in environmental history of the diffusion of forestry practice versus its modification induced by local conditions, environmental and political, Jones' case would suggest that it was not a simple either/or situation. A broad-based suite of supposedly universal forestry practices gave Jones the capacity to work in both subtropical and temperate environments with familiar and unfamiliar tree species. But local conditions could only overwrite his forestry practice if there are some canonical principles to be overwritten. Neither his professional training nor the influence of the locations in which he practised as a forester can be ignored. This is hardly a profound summation of Jones' career against a significant debate in environmental history, but at a more conceptual level Jones' career provides an empirical trace that reinforces Ulf Strohmayer's questioning 'the validity, the desirability, and the feasibility' of a separation of time from space. ${ }^{101}$ Independently, Seeds of Empire: The Environmental Transformation of New Zealand already stands as an example of the fruits of such a combined endeavour. ${ }^{102}$

101 Ulf Strohnayer, 'Historical Geographical Traditions', in Key Concepts in Historical Geography, ed. John Morrissey, David Nally, Ulf Strohmayer and Yvonne Whelen (London: Sage, 2014), 276.

102 Brooking and Pawson, Seeds of Empire. 
This text is taken from International Review of Environmental History, Volume 6, Issue 2, 2020, edited by James Beattie, published 2020 by ANU Press, The Australian National University, Canberra, Australia. 